\title{
Feedbackfaciliteter som et hjælpemiddel ved informationssøgning \\ - med inddragelse af semantiske problemstillinger
}

\section{Af Suzette Lindholm Kjær og Hanne Møller}

\section{Indledning}

Det er en kendsgerning at stadig flere slutbrugere har direkte adgang til informations-søgesystemer og eftersom slutbrugerne ofte er karakteriseret ved en forholdsmæssig lille IR-viden og en variende grad af emnemæssig viden, er det i høj grad påkrævet, at der sker en forbedring og udvikling af online søge- og hjælpefaciliteter.

Denne artikel vil beskæftige sig med udvalgte feedbackfaciliteter, og vurdere deres evne til at yde støtte og afhjælpe forskellige informationsbehov under en interaktions-proces mellem system og slutbruger. Feedbackfaciliteterne er afgrænset til klynger, rank/zoom og navigering, idet disse besidder et vist potentiale som støttemekanismer og er implementeret i eksisterende søgesystemer.

Artiklen tager udganspunkt $i$ det kognitive synspunkt, der fokuserer på samspillet mellem slutbruger og system. Imidlertidig er det kognitive synspunkt ikke konsekvent $i$ dets inddragelse af betydningsdannelsens kompleksitet. Denne mangel på konsekvens er problematisk, idet udveksling af information mellem slutbruger og system, bla. afhænger af søgesystemets begrebsmæssige arkitektur og indekseringspraksis. Derfor problematiseres semantikkens betydning ved at inddrage hermeneutikken, der sammenstilles med det kognitive synspunkt, og endvidere udbygges betydningselementet af Wittgensteins teorier om sprogspil og livsformer. Efter disse teoretiske overvejelser vil vi med en mere pragmatisk tilgang opstille nogle konkrete semantiske tiltag til forbedring af de tre selekterede feedbackfaciliteter.

\section{Det kognitive synspunkt}

De centrale grundlæggere af det kognitive synspunkt er Belkin, de Mey og Ingwersen. Et af grundprincipperne indenfor denne retning er, at forbedre de kvalitative kommunikationsveje af ønsket information mellem system og bruger (Ingwersen 1992, s. 15), og i modsætning til tidligere traditioner, fokuseres der på samspillet 
mellem brugerens informationsbehov og systemdesignet, og hvorledes disse er komplementære faktorer ved forbedring af IR.

En fremtrædende person under det kognitive synspunkt er ligeledes Marcia J. Bates der på basis af referencer til flere undersøgelser af søgeadfærd mener, at et informationsbehov ikke er stationært og upåvirket af feedback fra systemet.

Ifølge Bates er informationssøgninger snarere karakteriseret ved flere små successive søgninger, der bestandigt modificeres og ændres i søgeprocessen (bærplukningsmetoden):

"A bit-at-a-time retrieval of this sort is here called berrypicking. This term is used analogy to picking huckleberries or blueberries in the forest. The berries are scattered on the bushes; they do not come in bunches. One must pick them one at a time" (Bates 1989, s.410).

Idet et informationsbehov er dynamisk bør et søgesystem, ifølge Bates, være fleksibelt således at brugeren kan vælge mellem flere forskellige søgestrategier indenfor det samme system, alt afhængig af det aktuelle behov. I denne sammenhæng kan R. S. Taylor også nævnes, der på basis af undersøgelser af slutbrugernes informationsbehov, påviser de 4 Q-symboler (Taylor 1968, s.182):

$Q_{1}=$ Det ubevidste behov

Dette opleves som en vag følelse af utilfredshed, der oftest ikke er mulig at udtrykke med ord.

$Q_{2}=$ Det bevidste behov

Ønsket om information kan bestå af billeder, symboler.

$Q_{3}=$ Det formaliserede behov

Behovet kan beskrives sprogligt

$Q_{4}=$ Det kompromiserede behov

Ønsket om information præsenteres til formidleren, udfra forventninger til formidleren.

Ovenstående informationsbehov er ligeledes et aspekt der angiver, at problemløsninger og infor- mationssøgninger bestemmes af mange implicitte faktorer. For at et sådant informationsproblem kan afklares begynder en dynamisk dialog mellem eksempelvis bibliotekar og låner eller system og slutbruger, der gerne skal resultere i et match. Endelig kan nævnes Ingwersen, som på basis af protokolundersøgleser (Ingwersen 1992, s.116) klassificerer tre typer af adfærd:

\section{Verifikative informationsbehov}

Ønske om at verificere og lokalisere bestemte enheder (Taylors 3. stadie).

\section{Bevidst emneafgransede informationsbehov} Emneområdet er kendt for slutbrugeren (Taylors 3. stadie).

\section{Mudrede emneafgransede informationsbehov}

Slutbrugeren ønsker at udforske nye emneområder, men ved ikke hvordan man skal udtrykke problemet rent sprogligt (Taylors 1 . og 2. stadie).

Ovenstående usikkerhedsmomenter mellem slutbruger og system samt de tilfælde hvor slutbrugeren har varierende emnemæssig viden og lille systemviden er for os en indikator for, at slutbrugeren ikke umiddelbart kan søge i et komplekst søgesystem uden en søgespecialist som mellemled. Derfor finder vi det helt centralt, at systemet kan yde mere feedback end den traditionelle boolske logik kan tilgodese.

I følgende vil udvalgte feedback-teknikker inddrages og deres anvendelsesmuligheder beskrives og diskuteres, bl.a set i forhold til Ingwersen's tre typer af informationsbehov, hvorfor diskussionen vil foregå indenfor rammerne af det kognitive synspunkt.

\section{Feedback-faciliteter}

I følgende vil udvalgte feedback-faciliteter karakteriseres på baggrund af deres applikationsværdi som støttemekanisme og dialog-partner under søgeprocessen; der vil herunder fokuseres på faciliteternes egenskaber ved forskellige typer af 
informationsbehov samt deres evne til at stimulere brugeren under søgeprocessen.

Udvælgelseskriteriet ved valg af feedback-faciliteter er, at faciliteterne er i besiddelse af et vist potentiale som støttemekanisme, dvs. at de skal fungere som en hjælpefacilitet for brugeren og ikke forsøge at udvise menneskelig intelligens. Den ideelle interaktion mellem system og slutbruger er derfor præget af en løbende dialog, som medvirker til at slutbrugeren vha. egne associative evner og intelligens fremfinder relevante dokumenter. Som velegnede teknikker til dette formål"er henholdsvis prækoordinerede klynger og postkoordinerede klynger (rank/zoom) samt navigering valgt.

Disse feedback-faciliteter er dels udvalgt på baggrund af deres potentiale som stottefunktion, men også fordi de er implementerede i eksisterende systemer og $\mathrm{i}$ et levende miljø med nuancerede brugergrupper med forskellige typer af informationsbehov.

\subsection{Prækoordinerede klynger}

Klynger defineres meget overordnet som et forsøg på at samle beslægtede objekter. Dette indebærer samtidig muligheden for at det enkelte emenord kan befinde sig i flere forskellige klynger.

Generering af klynger er sædvanligvis en automatisk proces, hvor termhyppigheder og tærskelværdier angiver hvornår et emneord er relevant. Anvendelse af en konstant tærskelværdi er dog sjældent hensigtsmæssig, idet dette kan medføre enten meget store klynger eller meget små klynger. En variabel tærskelværdi er en måde at afhjælpe disse problemer, idet tærskelværdien er afhængig af, hvor mange emneord der findes indenfor et givet emneområde. Dvs. hvis den genererede klynge er for stor hæves tærskelværdien for på den måde at at splitte den store klynge op $\mathrm{i}$ mindre enheder.

Generelt vurderer vi klyngerne som en særdeles anvendelig feedback-facilitet ved både mudrede- og bevidst emneafgrænsede informationsbehov. Ved de mudrede informationsbehov fungerer klyngefaciliteten hovedsageligt som en støttemekanisme til at definere brugerens informationsbehov samt yde hjælp ved formulering af søgeforespørgsel, og ved de bevidst emneafgrænsede informationsbehov kan klyngerne anvendes til fremfinding af mere egnede og præcise søgetermer.

Ved begge typer af informationsbehov kan klyngefaciliteten karakteriseres som en slags idé-katalysator, der er i stand til at fungere inspirerende og stimulerende på slutbrugeren.

Kvaliteten af klyngerne er dog afhængige af en efterfølgende intellektuel bearbejdning, idet de er baserede på hyppighedsberegninger, hvorfor det altid vil være påkrævet med semantiske justeringer, hvilket kræver samarbejde med en fagspecialist, idet informationsspecialisten ikke har det nødvendige kendskab til samtlige emneområder.

\subsection{Postkoordinerede klynger}

Denne facilitet baseres på en relativ simpel frekvensanalyse af et sæt dokumenter, der rangordner de hyppigst forekommende termer $\mathrm{i}$ forhold til søgetermen $\mathrm{i}$ faldende orden. Hyppighedsberegningen kan udføres på forfatter, titel, emneord, tss., abstract m.m. Analysen kan bl.a identificere væsentlige forfattere eller kernetidsskrifter indenfor et emneområde. Frekvensanalysen kan altså bruges til at skaffe faktuelle oplysninger om et emneområde, f.eks. dets forfattere, tidsskrifter eller relevante emneord. Faren ved faciliteten ligger $i$ at analysen udelukkende baseres på statistiske beregninger uden nogen intellektuel bearbejdning. Dette forudsætter, at brugeren selv er i stand til at vurdere værdien af de rangordnede termer, dvs. har et vist fagligt kendskab til sit emneområde. Derfor er den bedste anvendelse af frekvensanalyse i forbindelse med verifikative eller bevidst emenafgrænsede informationsbehov. Problemet med den manglende kvalitative justering er størst $\mathrm{i}$ meget omfattende databaser, hvor forskellige paradigmer kan have helt divergerende opfattelser af det 
samme begreb. Således kan forfattere skrive indenfor det samme emneområde, men udfra helt forskellige synsvinkler og grundholdninger. Et andet problem med disse kvantitative faciliteter opstår $\mathrm{i}$ forbindelse med synonymer. Derfor må brugerne være bevidste om at andre relevante dokumenter kan findes indekseret under et andet emneord.

\subsection{Navigering}

Denne facilitet, som er søgninger i poster med mulighed for at navigere på tværs af de prædefinerede søgbare felter, afviger fra de statistiske beregningsmetoder, idet søgefaciliteten ikke nødvendigvis medfører en efterfølgende anvendelse af boolske operatorer, hvor emneord sammenkobles på baggrund af hyppigheder, men er derimod baseret på en associativ indeksering, hvor eksempelvis emneord, bibliografisk information, abstracts og referencelister er repræsenteret i systemet via netværk af knudepunkter og forbindelser/links. Via dette netværk er det muligt for slutbrugeren at navigere på tværs i systemet fra felt til felt, og er derfor en teknik der bl.a kan anvendes i både præog postkoordinerede klynger.

Ved anvendelse af navigeringsfaciliteten er det essentielt, at de tilladte navigeringsfelter ikke hovedsageligt er baseret på den deskriptive katalogisering, men ligeledes tillader navigering i felter, der indeholder kvalitative og emnerelaterede oplysninger. Dette er især påkrævet ved mudrede informationsbehov, hvor det skal være muligt for slutbrugeren selv at udforske de potentialer, der ligger i systemet (Bates 1986, s. 119), og eksempelvis navigere i klynger af emnerelaterede termer, abstracts osv. Ved disse vage og kompromiserede informationsbehov er det således væsentligt, at slutbrugeren bliver stimuleret og afprøver forskellige muligheder ved afgrænsning af informationsbehovet.

Navigering er dog ikke udelukkende for slutbrugere med vagt definerede informationsbehov, men kan ligeledes anvendes af slutbrugere med bevidst emneafgrænsede- samt verifikative informationsbehov, eksempelvis forfatter- og citationssøgninger. Navigerings-faciliteten henvender sig derfor ikke blot til ikke-vante slutbrugere og slutbrugere med et mudret informationsbehov, hvilket ofte er den generelle antagelse:

"But there is still a lingering tendency in information science to see browsing in contrast to directed searching, to see it as a causal, don'tknow-what-I-want behaviour that one engages in separately from "regular" searching" (Bates 1989, s. 414).

men er derimod en afspejlning af hvorledes slutbrugeres adfærd ofte karakteriseres ved informationsgenfinding i det fysiske miljø (Bates 1989, s. 412).

Navigering kan derfor karakteriseres som et forsøg på at afbillede en typisk brugeradfærd, som er kendetegnet ved at søge associativt og lade sig inspirere under en informationssøgningsproces. Denne brugeradfærd bliver af Bates betegnet som bærplukningsmetoden (Bates 1989, s. 410).

Som tidligere angivet er bærplukningsmetodens overordnede princip baseret $p a ̊$, at informationsbehovet ikke er en stationær størrelse og at der i nogle tilfælde hersker mange ligestillede potentielle søgebehov. Dette gør det vigtigt at fokusere på kvaliteten eller oplevelsen af selve søgeprocessen, hvilket eksempelvis kan være $\mathrm{i}$ form af veludviklede navigerings-muligheder. Det skyldes, at slutbrugeren i nogle tilfælde ikke er fikseret på et bestemt resultat, men ønsker at lade sig inspirere. Derfor navigerer slutbrugeren således rundt $\mathrm{i}$ systemet, og "plukker" lidt hist og her, idet ny information modtages under de enkelte søgninger. Det er derfor nødvendigt med mange små søgninger og anvendelse af forskellige søgefaciliteter, og den optimale søgestreng findes således ikke, men udgøres af mange små søgninger. 


\section{Introduktion af semantiske problemstillinger på basis af et teoretisk grundlag}

I ovenstående har vi koncentreret os om søgeadfærd og informationsbehov og fokuseret på udvalgte feedbackteknikker, der bl.a er vurderet udfra Ingwersens klassifikationer af tre typer søgeadfærd. Herunder har vi primært defineret os indenfor det kognitive synspunkt, der er en stærk og dominerende retning indenfor informationsvidenskaben og som oprindeligt udspringer af cognitive science. Cognitive science opstår i forbindelse med forskning indenfor kunstig intelligens i teknisk-naturvidenskabelige kredse i 1970'erne.

Kendetegnet for cognitive science er, at ord betragtes som kontekstfrie, objektivt-leksikalt beskrivende symboler eller data, hvilket betyder at der hersker et meget formelt syn på sprog i disse kredse.

Det er således dette aspekt der skal behandles i det følgende, idet det kognitive synspunkt på trods af en åbning af cognitive science, hvor betydningselementet $\mathrm{i}$ informationsbegrebet til en vis grad inddrages, stadig har bindinger til cognitive science. Det kognitive synspunkt teoretiserer således ikke i særlig høj grad over, og fokuserer på hvordan mennesket erkender og hvorledes ord/sætninger får betydning.

Dette finder vi er en helt central problemstilling i forbindelse med en dybere kvalitativ vurdering af feedbackteknikkernes egnethed og for at skabe forståelse for emneindekseringsproblematikken, således at der kan ske en reel informationsudveksling mellem system og slutbruger

Vi ønsker derfor at inddrage hermeneutikken der skal bidrage med en teori om hvordan mennesket erkender og hvorledes sprogets semantiske indhold netop får sin betydning $i$ en social og historisk kontekst. Dette skal endvidere uddybes med filosoffen Wittgensteins teorier om sprogspil og livsformer.
Endvidere vil de forsøg som det kognitive synspunkt gør for at åbne op for hermeneutiske aspekter diskuteres, hvorunder de tiltag som Ingwersen har bidraget med, præsenteres og diskuteres udfra nogle selekterede punkter, som vi finder vigtige. Afslutningsvis skal de tre udvalgte feedbackteknikker inddrages, og vurderes i forhold til opbygningen af det semantiske indhold, der netop skal resultere $\mathrm{i}$ information mellem slutbruger og søgesystem.

\subsection{Hermeneutikken}

Som baggrund for en diskussion og sammenligning af det kognitive synspunkt og hermeneutikken, og for således at undersøge om hermeneutikken kan tilføre de udvalgte feedback-faciliteter forbedringer, skal hermeneutikken introduceres.

Vi skal i følgende fokusere på dele af den filosofiske hermeneutik, der i 1900-tallet bliver grundlagt som egentlig videnskab og baserer sig på Martin Heidegger og hans elev Hans Georg Gadamers teorier.

Det der analyseres er menneskets dagligforståelse af sig selv og tingene, og den konkrete dagligdagstilværelse betegnes som ontisk eller eksistentiel. Heidegger taler om at menneskets eksistentielle vilkår er, at vi er kastet ud i verden og sproget og står $\mathrm{i}$ et umiddelbart forhold til de ting $\mathrm{i}$ omverdenen der omgiver det (Christensen 1994, s.27).

Dette er således et brud med hele den videnskabelige og rationelle opfattelse af mennesket, der kan forholde sig objektivt til tingene og aflæse og manipulere med en verden, der ligger uden for mennesket selv.

Heidegger opererer med et før-bevidst brugsforhold, hvor en tings' mening skabes i dens brugsforhold, og hvor vi netop kan bruge tingene uden at have en bevidst opfattelse af dem. Dette skyldes, at mennesket er tilstede i tingene som det bruger (Christensen 1994, s.27). Ovenstående er således et forsøg på at forklare menneskets forhold til 
repræsentationer hvor mennesket således er kastet ud i verden før selve begrebsdannelsen og derfor først og fremmest står $i$ et praktisk og socialt forhold til omverdenen, hvor det ikke er muligt objektivt og distancerende at forholde sig til begreber og ting (repræsentationer).

Gadamer tager også udgangspunkt i den praktiske livsverden og ser sproget som kernen til en stadig dynamisk forståelse af verden.

Når man i hermeneutikken først og fremmest taler om sprog og sekundært om begreber skyldes det at man ikke vil adskille sproget og den historie, som sproget er forbundet med. Forskellige holdninger bliver i kraft af deres sproglige udtryk andet og mere end en ytring af et enkelt subjekts holdning, det sproglige udtryk vil påvirke andre i deres meningsdannelse." (Christensen 1994, s.29)

Her inddrages således tanken om den menneskeligekulturelle kontekst, hvor den korrekte betydning af et givent semantisk indhold ikke ligger i sproget alene men $i$ den praktiske livsverden (historie). Herved får sproget en praktisk funktion, der er årsagen til at det overhovedet eksisterer.

Centralt for Gadamer er fortolknings-processen, dvs. for at forstå en tekst eller et andet menneske må vores forståelseshorisont (forforståelse) falde sammen med det fortolkedes forståelseshorisont. Forståelseshorisonten består af private og sociale livsformer der bla. indeholder kultur og traditioner forstået som en dynamisk proces hvor horisonter kan udvides og ændres via eksempelvis en sproglig dialog, hvilket kaldes horisontsamensmeltning (Christensen 1994, s.29). Enhver repræsentation er således en fortolkning, hvor det herefter igen kan afvises at begreber står $i$ et entydigt forhold til omverdenen.

På basis af denne korte fremstilling af de teorier som henholdvis Heidegger og Gadamer opstiller kan vi indse, at der sker et brud med hele den. videnskabelige rationelle opfattelse af mennesket. Mennesket beskrives således i disse teorier som værende et socialt væsen, der er bundet til verden og sproget som det altid vil være en del af.

Det afvises endvidere, at erkendelse baserer sig på repræsentationer, idet mennesket er kastet ud i verden for enhver begrebsdannelse og står $\mathrm{i}$ et praktisk brugsforhold til tingene. Dvs. at betydningen af en given handling eller af sproget må findes i en kompleks og dynamisk social og kulturel kontekst, hvori tingene udføres/praktiseres. Endelig kan nævnes at for at få erkendelse må mennesket bestandig fortolke sine omgivelser udfra en given forforståelse, der er underliggende for al tanke og handling, og som aldrig til fulde kan udtrykkes eksplicit.

Det kognitive synspunkt har åbnet op for dele af hermeneutikkens teorier og $\mathrm{i}$ følgende skal Ingwersens tiltag diskuteres ud fra centrale temaer, for at undersøge om hermeneutikken har en indvirkning på teorierne og kravene til feedback-faciliteterne indenfor det kognitive synspunkt.

\subsection{Sammenligning af det kognitive synspunkt og hermeneutikken}

Indledningsvis skal det her nævnes, at det kognitive synspunkt, ifølge Ingwersen, er tættere knyttet til hermeneutikkens teorier end til rationalismen, der bla. kommer til udtryk i cognitive science (Ingwersen 1992, s.41).

Ingwersen ønsker dermed at åbne op for hermeneutiske aspekter og sammenstiller således begreber indenfor dels det kognitive synspunkt og hermeneutikken, for således at vise de mange fællestræk og relativt få divergenser, der hersker mellem de to retninger. Vi er ikke enige i sammenstillingerne, idet vi finder at denne åbning mod hermeneutikken på flere punkter blot er en modificering og justering af det kognitive synspunkt. Begreber fra hermeneutikken diskuteres således uden at det reelt får konsekvenser for teorier om erkendelse og begrebsdannelse i det kognitive synspunkt, hvilket skal underbygges i følgende. 
Ifølge det kognitive synspunkt er den største lighed mellem cognitive science og det kognitive synspunkt reprasentationsbegrebet, selvom begrebet er modificeret under det kognitive synspunkt. Repræsentationsbegrebet angiver en tro på, at det er muligt vha. tegn/data at repræsentere og afspejle den eksterne verden objektivt, og at betydningen af information behandles på et formelt og logisk niveau:

"The only core issue in common between the cognitive view and "Cognitivsm" in relation to cognitive science is the notion of "representation". However as argues previously, the cognitive view acknowledge a much wider interpretation af this fundamental concept, incorporating meaning" (Ingwersen 1992, s.38).

Indenfor det kognitive synspunkt bibeholdes altså repræsentationstankegangen, hvor mennesket således kan forholde sig objektivt og logisk manipulerende til omverdenen omend denne tanke bliver modificeret indenfor det kognitive synspunkt. Til trods for denne åbning eller modificering er udgangspunktet dog stadig, at man indenfor det kognitive synspunkt anvender computeren og dens måde at behandle information på, som en slags model for hvordan hjernen fungerer, hvilket man på basis af hermeneutikkens teorier om erkendelse og begrebsdannelse ikke kan acceptere. Vi mener således, at Ingwersen på dette afgørende punkt viser, at han på trods af gode intentioner om inddragelse af hermeneutikken ikke drager den fulde konsekvens, idet han efter vores mening er bundet til nogle af teorierne indenfor cognitive science, og stadigvæk bevidst er indfanget af repræsentationsbegrebet, der er grundlæggende for cognitive science og ikke harmoniserer med hermeneutikkens grundantagelser.

Ingwersen sammenstiller ligeledes det kognitivistiske begreb vidensstrukturer med det hermeneutiske begreb horisont og selvom mange lighedstrak præger de to begreber, er der dog en afgørende forskel, idet det kognitive synspunkt i høj grad er individcentreret i modsætning til hermeneutikerne, der har et grundlæggende socialt udgangspunkt. Horisontbegrebet har ligeledes en bredere definition end vidensstrukturbegrebet, da førstnævnte betoner traditioner, historie, den enkeltes optagethed/involverethed $i$ den praktiske livsverden og følelsesmæssige aspekter, hvilket medvirker, at horisontbegrebet består af mange implicitte og ubevidste faktorer. Det kognitive synspunkt er derimod primært præget af en individualisering og en vis grad af objektivitet og ekspliciterbarhed, men Ingwersen åbner dog flere steder i sin Ph.D (1992) op for at de mentale modeller (vidensstrukturer) har rod i en ikke-bevidst praksisverden.

Der er således igen tale om en åbning mod hermeneutikken, men også her kan der påvises et ambivalent forhold. Dette kommer bl.a til udtryk i graden af objektivitet og ekspliciterbarhed samt i det øjeblik hvor slutbrugeren skal søge information på grund af en ufuldstændig mental repræsentation, som det således udtrykkes indenfor det kognitive synspunkt, og som ofte efterfølges med en informationssøgning for på denne måde at udvide og "forbedre" mentale modeller indenfor et bestemt emneområde, dvs. en bevidst handling pga. ønsket information. I forsøget på at nærme sig de hermeneutiske tanker, sammenligner Ingwersen denne ufuldkomne mentale repræsentation i vidensstrukturerne med det hermeneutiske break-down begreb.

Break-down begrebet er en afløsning af kastetheden (thrownness), hvor man agerer ureflekterende i en velkendt verden. Hvis der derimod opstår en situation, hvor ens handlinger/evner er utilstrækkelige, og man derfor er henvist til en mere bevidst reflekteren og handlen befinder man sig i en breakdown situation. Break-down situationer kan bl.a løses ved opnåelse af information, og fungerer derfor som en katalysator for en informationssøgning. Ingwersen er bevidst om, at de to begreber er nært-beslægtede men ikke identiske.

Det følgende citat illustrerer tydeligt, at Ingwersen står med et ben i hver lejr, dvs. at han prover at inddrage hermeneutiske begreber, som $i$ høj grad fortolkes ud fra det kognitive synspunkt: 
"The take-over by the individual's subjectivity from his social/collective and historical reality, grounded in his previous experiences, happens exactly when he begins to read a book or instigates the IR system, interpreting the screen contents" (Ingwersen 1992, s. 46).

Citatet illustrerer klart bevægelsen væk fra den sociale og praktiske kontekst henimod den karakteristiske individualisering og fokus på den enkeltes vidensstrukturer. En sådan skelnen mellem individet og den sociale og kulturelle kontekst er dog ikke muligt set ud fra et hermeneutisk synspunkt, idet individet ikke er $\mathrm{i}$ stand til at løsrive sig fra den sociale sfære, men altid vil være præget af en optagethed og derfor konstant være bundet til omverdenen og en social kontekst.

Vi mener derfor, at Ingwersens pointering af individualiseringen i søgeøjeblikket klart tilkendegiver, at den hermeneutiske synsvinkel ikke spiller en særlig markant rolle indenfor det kognitive synspunkt.

Idet Ingwersen påpeger at slutbrugeren er præget af subjektivitet og individualitet under søgeprocessen, er det således disse faktorer der efter hans mening, bør fokuseres på, ved udvikling af feedback- og interfacefaciliteter, og ikke kulturelle faktorer samt den sociale kontekst.

Idet det kognitive synspunkt har indset den stærke påvirkning af mennesket fra den praktiske livsverden inddrager Ingwersen Luria, og undersøglsen af henholdsvis kategori- og situationsklassifikation. Kategoriklassifikation er den logisk-abstrakte måde, at opdele ting på, "based on abstract principles" (Luria 1976, s. 54), og situationsklassifikation er den praktiske måde, at opdele ting på, "objects suitable for a specific purpose" (Luria 1976, s. 54).

Kategori- og situationsklassifikation er dog også et udtryk for troen på, at det til en vis grad er muligt objektivt at klassificere og repræsentere begreber uden hensyn til kontekstafhængigheden. Problem- stillinger som peger på, at det semantiske indhold ofte ligger i den praktiske livsverden og i konkrete situationer uddybes ikke, hvorfor Ingwersen heller ikke indddrager den hermeneutiske grundholdning, der understreger at enhver repræsentation er en fortolkning, og begreber derfor ikke står $\mathrm{i}$ et entydigt forhold til omverdenen.

Afslutningsvis skal det nu nævnes, at hermeneutikken ikke umiddelbart har den store teoretiske indvirkning på udvikling af feedback-faciliteter indenfor det kognitive synspunkt. Efter vores mening bidrager hermeneutikken dog med sine eksistentielle teorier med nogle helt centrale faktorer om en historisk og social forforståelse. Endvidere får vi nogle interessante teorier om sproget, hvor det på basis af dette må afvises at begreber kan stå $\mathrm{i}$ et entydigt forhold til omgivelserne og hvor enhver form for erkendelse găr via fortolkning af omverdenen, hvor mennesket således tillægger ting og artefakter en betydning.

Ovenstående hermeneutiske indfaldsvinkler kan således relateres til den mere impulsive og irrationelle måde at søge information på, som beskrives tidligere i artiklen, og som netop er et udtryk for at mennesket ofte ikke har et afklaret rationelt forhold til tingene ved eksempelvis en problemløsnings- eller informationssøgnings fase, men derimod må forsøge sig frem og langsomt arbejde sig ind i tingene på baggrund af dialogformen.

Det er således på basis af hermeneutikken muligt at finde et teoretisk/filosofisk grundlag for at dialog eller interaktion mellem system og bruger er helt centralt ved horisontsammensmeltning. Herunder er kontekst centralt for at forstå den rette semantiske betydning af et ord, og idet det er i den aktuelle livsverden, at begreber får betydning finder vi det nu vigtigt at introducere Wittgensteins teorier om sprogspil og livsformer.

\subsection{Sprogspil og livsformer}

Tidligere $\mathrm{i}$ artiklen er hermeneutikken blevet præsenteret, der giver en interessant filosofisk 
forståelse af tingene og den menneskelige eksistens' karakter og sproget som kernen i al forståelse. I følgende ønsker vi endvidere at inddrage Wittgensteins teorier om sprogspil og livsformer, der skal uddybe betydningsdannelses-aspektet.

For Wittgenstein er det den menneskelige praksis og det sociale/kulturelle liv (livsformer) der skaber konteksten eller rummet indenfor hvilken sproget eller mere specifikt sprogspil kan få deres rette betydning (Blair 1990, s.135).

Det fundamentale princip for betydning er altså at se på den funktion sproget eller tegnet har set $i$ en given livspraksissammenhæng, hvorved forholdet mellem sprog og social/kulturel praksis bliver uløseligt sammenflettet.

Ligesom vi så det hos hermeneutikken forkastes tanken om objektiv repræsentation, idet sproget blot er nogle konventioner for hvad vi kalder tingene.

Kontekstbegrebet er allerede introduceret via hermeneutikken, og det interessante for os, set i forhold til dokumentrepræsentation i IR-systemer er det faktum, at Wittgenstein introducerer vigtigheden af at se på funktionen af et ord:

"If we ask how the screwdriver is used in a specific situation, the ambiguity is used in a specific situation, the ambiguity is resolved, or at least lessened.(Blair 1990, s.140)

Herved kan det komplekse og tvetydige element der ligger i sproget mindskes, idet ethvert sprogspil er knyttet til en bestemt form for livspraksis. Det er disse forskellige praksisformer det er vigtig at afdække og forstå, når vi taler om hvordan dokumenter forståelsesmæssigt skal repræsenteres i søgesystemer for at der skal forekomme et match mellem system og slutbruger.

Disse tanker blev også præsenteret af Taylor, hvor vigtigheden af emnedefinitions-processen og forespørgelsens årsag, formål og motivation er centrale for at forstå lănernes informationsbehov $\mathrm{i}$ en kontekst.

Om indlæring mener Wittgenstein, at sprogspil er sammenkædet med specifikke aktiviteter og eksempler, og barnet lærer at mestre disse sprogspil ikke gennem forklaringer og definitioner, men gennem eksempler i konkrete sammenhænge (Blair 1990, s. 150).

Definitioner tildeles også en rolle, men de fungerer blot når personen har basis-viden for hvordan ordene kan bruges, hvilket kommer således til udtryk hos Blair:

"Once we understand the general form of usage (language game) of a word/phrase and are personally familiar with the activities (forms of life) in which it is used, then and only then can definitions and explanations help to highlight certain significant or important aspects of the usage" (Blair 1990, s.162)

Vi må således være enige om hvilken livspraksissammenhæng vi taler om for at kunne forstå hinanden. Det er således denne livspraksissammenhæng det er vigtigt at analysere og indkorporere $i$ IR-systemer og herunder også feedbackteknikker. Blair mener, at en online søgeproces i højere grad skal efterligne den måde mennesket kommunikerer på, idet vi ikke taler om et emne $\mathrm{i}$ form af en liste af emneord, men derimod udvider, justerer og eksemplificerer vores definitioner. Vi søger således at nå en fælles basis for lingvistiske beskrivelser indenfor hvilke vi spiller det samme sprogspil (Blair 1990, s. 174).

I følgende skal hermeneutikken og Wittgensteins teorier om bl.a betydningsdannelsens kompleksitet og vigtigheden af kontekstualitet nu sættes i forhold til de udvalgte feedback-faciliteter: klynger, zoom/rank og navigering, idet de således skal bidrage med forslag til semantiske forbedringer af disse. 


\section{Krav til feedback-faciliteter på baggrund af hermeneutikken og Wittgensteins teorier}

Der vil i dette afsnit opstilles pragmatiske og praksisorienterede forslag til forbedring af de udvalgte feedback-faciliteter på baggrund af ideer fra hermeneutikken og Wittgensteins teorier om sprogspil og livsformer. Hermeneutikken og Wittgensteins teorier medfører, at der i høj grad vil fokuseres på faciliteternes begrebsmæssige arkitektur og indekseringspraksis, som metoder til at forfine faciliteterne. Det er i denne sammenhæng vigtigt at pointere at de kvantitative og automatiske teknikker, klynger og ranking, udspringer fra den systemdrevne tradition, dvs. at teknikkerne bygger på synsvinkler, som i særdeleshed strider mod Wittgensteins og de hermeneutiske grundantagelser.

Det kan derfor virke paradoksalt at anvende hermeneutikken og semiotikken til at forbedre de eksisterende teknikker, som hviler på et helt andet grundlag. Ved en anvendelses- og pragmatisk orienteret tilgang, vil faktum dog være en tillempning af generelle teorier, hvilket $i$ dette tilfælde bevirker, at erkendelsesmæssige og filosofiske ideer skal afpasses, så de passer ind i systemer, der hviler på et logisk-matematisk ideal.

Nedenstående skal således opfattes som konstruktive forslag der accepterer det kognitive synspunkt, men som tilstræber forsøget på at eksplicitere og være mere bevidste om de nuværende ulemper indenfor det kognitive synspunkt, og dermed nødvendigheden af $i$ højere grad at inddrage tegns betydning, fortolkningsaspektet samt det faktum at begreber ikke står i et entydigt forhold til omverdenen.

\subsection{Prækoordinerede klynger}

Konstruktion af klynger er som tidligere nævnt et forsøg på at vise slægtskab mellem termer, dvs. en form for kontekst, der skal hjælpe brugeren til begrebsafklaring. Klynger kan således medvirke til at give brugeren forståelse for søgesystemets begrebsmæssige opbygning og hvilke synsvinkler, der kan lægges på en given term. Det er derfor en støttemekanisme, hvor slutbrugeren selv interaktivt beslutter hvilken synsvinkel, der er den ønskede. Imidlertid er klyngekonstruktion baseret på statistiske metoder, hvorved termerne rives ud af en oprindelig sammenhæng og optræder isoleret. Dette er problematisk, idet sprogbrug altid relaterer sig til den sammenhæng hvori den foregår, dvs. en naturlig og original kontekst. Vi kan derfor udvide den tidligere nævnte kvalitative justering af klyngerne til at den skal indeholde information der befordrer kontekst, som går udover den som findes i selve dokumenterne (Blair 1990 s184). Dette er især vigtigt, da klyngerne som tidligere nævnt er velegnede til mudrede og bevidst emneafgrænsede informationsbehov. Derfor skal brugerne ikke kun have oversat sit informationsbehov, men inspireres med nye ideer og hjælpes til at placere sig i den rette kontekst.

Metoden til at opnå kontekst udover dokumenterne bliver nødvendigvis at tage udgangspunkt i slutbrugerne. Dette kan ske ved dels at undersøge hvorledes slutbrugere konkret søger information, f.eks ved at analysere specifikke søgeformuleringer og inddrage informationsspecialistens erfaring med brugerforespørgsler. Dels kan man undersøge hvilken viden slutbrugerne besidder fra deres praktiske livsverden. Herved tager hermeneutikken udgangspunkt $i$ det daglige, hvor ord får betydning $i$ en praktisk sammenhæng. Det skal dog understreges at hermeneutikken i sig selv aldrig vil anerkende automatisk konstruerede klynger, men netop vil begynde med undersøgelser af den praktiske livsverden og derfor udelukkende anvendelse af kvalitative metoder.

En metode til at inddrage slutbrugernes praktiske livsverden er ordassociationstesten, som det kognitive synspunkt inddrager.Det kognitive synspunkt tror til en vis grad at begreber kan repræsenteres objektivt, men indser dog, at tegn skal relateres til en kontekst, en social-historisk praksis. Derfor forsøger de at åbne op for den mere praktiske dagligdagsanvendelse af termer ved at inddrage 
situationsklassifikation, som bla. udløses gennem en ordassociationstest. Denne metode tager udgangspunkt $\mathrm{i}$ individet og baseres på enkeltord, hvorved den kan hjælpe til at afdække det enkelte individs praktiske opfattelse af en term. Vi mener, at ordassociationstesten til en vis grad kan være en metode til at opnå forståelse for en terms brugssammenhæng, forudsat at det givne ord som respondenten skal associere til, er placeret $i$ en praktisk brugssammenhæng således at ordassociationen foregår indenfor den rette kontekst. Herunder kan det påpeges, at det er påkrævet, at testen altid bearbejdes kvalitativt. Endvidere kan det nævnes at ordassociationstesten er velegnet $\mathrm{i}$ situationer hvor indeksøren skal have kendskab og forståelse for sine brugeres terminologi, idet indeksøren må tilpasse sig brugernes behov.

Ordassociationstesten opprioriterer dog i høj grad individualiseringen, hvorimod der $i$ en hermeneutisk tilgang $i$ højere grad ville anvendes kvalitative tilgange, som eksempelvis en kollektiv vedtagelse af termers betydning via samtalen.

For at skabe konsensus om betydningen af en specifik term og dens konventionelle anvendelse er det en fordel at have rod i fælles livspraksissammenhæng. Dette kan tildels opnås ved at afgrænse sin målgruppe, f.eks. til små in-house systemer. Som eksempel kan nævnes en ordassociationstest, der udførtes på en handelsskole bestående af markedsøkonomer og datamatikere, der tydeligt illustrerede de forskellige brugssammenhænge den samme term havde på de to uddannelser (Lindholm Kjær, Sognstrup og Møller 1994, s.116). Men selv små steder med fă ansatte kan have forskellige syn på den sammenhæng en term optræder i. Lykke Nielsen og Skrubbeltrang udførte i 1992 en ordassociationstest med 9 personer indenfor et snævert fagområde, hvor deres resultater viste, at personernes tidligere uddannelser og arbejdspladser tydeligt blev afspejlet $i$ deres forståelse af begrebers betydning (Lykke Nielsen og Skrubbeltrang 1992, s. 82). Dette bekræfter, at den praktiske livssammenhæng er essentiel for sprogbruget. Det er derfor vigtigt at anskueliggøre et systems brug af termer, hvilket Blair kalder the learnable system (Blair
1990 , s. 178). Begrebet er tæt forbundet med Wittgensteins sprogspilside, idet man skal lære sprog og ord gennem eksempler.

Blair mener, at det er en grundlæggende forudsætning for interaktion, at slutbrugeren lærer systemets specifikke brug af termer at kende for at kunne interagere. Selvom klyngerne bliver dannet vha. termer der hentes udenfor dokumenterne $\mathrm{i}$ slutbrugernes verden foreslår Blair yderligere, at man i relation til en given søgeterm făr fremvist de klarest mulige eksempler på dokumenter, der indeholder denne term (Blair 1990, s.180). Dette kunne tænkes at være referencer der viser hvilke termer et dokument indeholder og desuden et abstract så slutbrugeren kan vurdere, hvor relevant dokumentet er i forhold til søgetermen. En anden metode til at lære slutbrugeren systemets opbygning er at vise eksempler på fuldstændige søgeprocesser og derved anskueliggøre hvorledes en vellykket søgning fungerer og hvorledes termerne er anvendt.

\subsection{Postkoordinerede klynger}

Rank/zoom kommandoen er en facilitet der benyttes af slutbrugeren under den aktuelle søgning, hvorfor det ikke er muligt intellektuelt at justere den hyppighedsbaserede sammenkobling af termer. Som tidligere angivet mener vi dog, at kvalitative justeringer er uundværdige, såfremt acceptable resultater skal fremkomme ved kvantitative sammenkoblinger af termer. Dette skyldes, at automatiske metoder altid er behæftede med en vis risiko for fejlplaceringer af termer, idet termer automatisk udtrækkes af deres naturlige kontekst, hvor de făr betydning.

Dette medvirker, at faciliteten hviler på et meget tvivlsomt grundlag, idet ovenstående tilfældighedsprincip ikke tilgodeser semantiske aspekter, hvilket i høj grad kan forvirre alle typer af informationsbehov.

En faktor der ligeledes forstærker de negative sider ved rank/zoom kommandoen er, at de i særdeleshed er baseret på bibliografiske oplysninger samt 
udtrukne og dokumentorienterede termer, der ikke fremmer den begrebsmæssige erkendelse hos brugeren.

Rank/zoom faciliteten er således baserede på det objektivistiske og reduktionistiske repræsentationsbegreb, hvor termer ikke nødvendigvis bør fremstilles i en kontekst, en forestilling om at relationerne mellem termer til en vis grad kan defineres via frekvensberegninger, ingen krav om tildelte termer og at den enkelte term ofte har en begrænset betydning:

"Naturally, a zoom list is not a semantic structure in line with case-frames or thesauri. However, there exists always a semantic relation between the original search-profile and the zoomed outcome" (Ingwersen 1992, s. 185186).

Dette er fundamentalt i strid med både de hermeneutiske grundtanker og Wittgenstein, som ikke accepterer universelle og kontekstfrie definitioner. Hermeneutikkerne fokuserer i høj grad på fortolkningsaspektet hos den enkelte person, som er baseret på forforståelsen og den praktiske livsverden, til at bestemme betydningen af det enkelte begreb. Wittgenstein henter betydningen af ord fra de faktisk kommunikative situationer fra det levede liv (sprogspil og livsformer), hvorfor der ikke kan leveres entydige definitioner, som idealet er indenfor et logisk-matematisk ideal.

På baggrund af ovenstående er vores generelle holdning derfor, at rank/zoomfaciliteten er yderst tvivlsom i store internationale databaser som f.eks DIALOG og ESA/IRS, idet det ikke er muligt at tage højde for alle fortolkninger og brugssammenhænge af et begreb, hvilket medfører at termer ofte vil forekomme i en anden kontekst end forventet. Ligeledes kan brugere med en ikke særlig veludviklet system- og emnemæssig viden i høj grad miste mange værdifulde dokumenter pga. den manglende transparens.
Derimod mener vi, at faciliteten har en brugsværdi i små in-house systemer med en afgrænset og veldefineret målgruppe. Rank/zoomfaciliteten kan herefter konstrueres således at den tilpasser sig organisationens behov, dvs. at eksempelvis emneordsfeltet består af emneord der i højere grad refererer til brugssammenhænge, der fremfindes på baggrund af udtømmende og kvalitative brugerundersøgelser.

\subsection{Navigering}

Indledningsvis skal det som tidligere fremhæves, at navigeringsteknikken ikke baserer sig på automatiske metoder, hvor termer således sammenstilles og genereres på basis af matematiske hyppighedsberegninger. Derimod kan alle former for bibliografisk information og emneindeksering præsenteres i systemet via knudepunkter og forbindelser (links), som kan defineres af eksempelvis indeksør/informationsspecialist.

Links og indhold i felter skal herefter udarbejdes på basis af kvalitative brugerundersøgelser, hvor viden om termers betydning $i$ en praksissammenhæng og kendskab til livsformer og sprogspil kan afdækkes og analyseres. Felter kan herefter tildeles nogle kvalitative emneoplysninger, der således henvender sig specifikt til målgruppe og arbejdsområde. En sådan analyse er således helt central udfra hermeneutikken og Wittgensteins teorier om sproget, hvor meningsdannelse får sit korrekte semantiske indhold i en praktisk kontekstuel sammenhæng. Navigerings-faciliteten kan naturligvis også baseres på kvantitative data. For at tilgodese hermeneutikkens og Wittgensteins grundantagelser, er det dog særdelses vigtigt at navigeringsfaciliteten er baseret på kvalitative oplysninger.

En sådan kvalitativ analyse giver efter vores mening en større sandsynlighed for kollektiv horisontsammensmeltning mellem en brugergruppe og et informationssystem. Dette skyldes, at der er foregået en slags præanalyse og fortolkningsproces, hvor forskellige links er konstrueret og felter er tildelt kvalitative emnebeskrivelser, udfra praktiske brugs- og sprogspilssammenhænge indenfor et 
afgrænset specialområde, der kendes af slutbrugeren. Denne afgrænsning er som tidligere påpeget central på grund af sprogets kompleksitet og mange betydningsaspekter.

Idet navigerings-teknikken således ikke hviler på et kvantitativt grundlag og i hø̋ grad er i stand til at stimulere og inspirere brugeren under søgeprocessen, mener vi, at denne teknik er den mest velegnede af de tre feedbackteknikker, såfremt de emneord og felter, hvor det er muligt at navigere, afspejler slutbrugerens sprog og livspraksis. Dette skyldes at den har de bedste forudsætninger for at tilgodese betydningsdannelsens kompleksitet og herved tilgodeser de hermeneutiske tanker og Wittgensteins teorier.

Søgeteknikken henter også sin force i det faktum at navigering ofte er en afspejling af hvorledes søgeadfærd typisk forløber. Bates giver udtryk for at informationssøgninger er karakteriseret ved flere små successive søgninger, der bestandigt modificeres. Herunder kan også nævnes Blair der nævner, at en søgeproces er en trial-and-error proces (Blair 1990, s.6):

Endvidere kan dette understøttes af hermeneutikkens teorier, hvor mennesket således handler udfra, og er begrænset af sin forforståelse eller videnshorisont, der ifølge Gadamer dynamisk kan ændres i dialog. Her ser vi især navigering, men til dels også de øvrige feedback teknikker som en potentiel dialogpartner, hvor interaktion udfra den samme opfattelse af sprogspil, kan medføre en frugtbar horisontsammensmeltning mellem målgruppe og system.

Herunder kan også nævnes generelt for feedbackteknikker, at de kan fremvise systemets potentielle information, således at sprogspillet bliver synligt for slutbrugeren. Herunder er det vigtigt at nævne, at systemet må udvise en så høj grad af transparens som mulig, således at slutbrugeren kan sikre sig, at der spilles efter de samme spilleregler, så dialogen bliver retfærdig og jæunbyrdig.

\section{Konklusion}

I de senere år har det kognitive synspunkt været medvirkende til at fokus i højere og højere grad har været rettet mod nødvendigheden af en øget indsats overfor støttefunktioner i bruger-system dialogen.

Udgangspunktet i nærværende artikel har været at belyse og problematisere støttemekanismerne i et søgesystem vha. tre udvalgte feedback-faciliteter: klynger, rank/zoom og navigering.

De tre udvalgte feedback-faciliteter er vurderet og diskuteret på baggrund af forskellige kriterier, såsom faciliteternes værdi ved afgrænsning og afklaring af slutbrugerens informationsbehov, deres evne til at stimulere og give brugeren nye ideer og synsvinkler indenfor et emneområde samt i hvor høj grad teknikkerne tillader kvantitative og semantiske justeringer.

Ved vurderering af de tre feedback-faciliteter, kan det konkluderes at de alle har et fremtidigt potentiale, dog med forskellig styrke, idet vi generelt mener at de er i stand til at give nye ideer, inspirere, vise systemets potentielle information, medvirke til at opdage nye sammenhænge samt støtte brugeren ved begrebsafklaring.

Problemets kerne ved de nuværende feedbackfaciliteter er dog, at de har rødder $\mathrm{i}$ en informationsvidenskab med et rationelt og objektivistisk udgangspunkt - cognitive science. Dette medfører at mange af faciliteterne (eksempelvis klynger og rank/zoom) er baserede på kvantitative og automatiske teknikker, der medvirker mange metodiske problemstillinger, bl.a. manglende hensyntagen til begrebers kontekst-afhængighed.

Ingwersen, en af frontfigurerne indenfor det kognitive synspunkt, forsøger dog at åbne op for hermeneutikken og Wittgenstein, men der kan påpeges en mangel på konsekvente eksplicitte teoretiske overvejelser om menneskets erkendelse og betydningsdannelsens natur. 
Idet vi mener at de nuværende feedback-faciliteter kan forbedres, inddrager vi både hemeneutikken og Wittgenstein som en supplerende indfaldsvinkel. Der brydes hermed med idealet om en objektiv repræsentation og anskuelse af computeren som en model for den menneskelige hjerne, til fordel for en mere realistisk opfattelse af mennesket som et irrationelt væsen, der således eksisterer i, og er en del af den praktiske livsverden, som det ikke kan hæve sig over og anskue objektivt. Mht. fortolkningsprocessen kan det konkluderes, at mennesket forholder sig fortolkende til omverdenen og at al erkendelse udspringer fra den forforståelse (social og kulturel), som mennesket orienterer sig ud fra. Det er således evident, at mennesket ikke står $\mathrm{i}$ et entydigt forhold til begreber og ting i omverdenen. Her introduceres dialogen som det centrale for at bringe to horisonter sammen til en horisontsammensmeltning.

Til forbedring af de nuværende feedback-faciliteter har hermeneutikken og Wittgenstein for os bidraget med en forståelse for nogle generelle og pragmatiske antagelser, såsom vigtigheden af at feedbackfaciliteterne anvendes i små in-house systemer med en afgrænset målgruppe. Ligeledes er det væsentligt at feedback-faciliteterne er baserede på en indekseringspraksis, der er udarbejdet på baggrund af kvalitative brugerundersøgelser. Ved udarbejdelse af disse undersøgelser er det nødvendigt at forstå organisationens kultur og funktioner ud fra en ligevægt mellem organisationens interesser og indeksøren/systemets interesser, som eksempelvis kan være interviews eller ordassociationstests, således at informationsspecialisten făr et vist kendskab til brugerne.

Dette grundige kendskab til brugergruppen er påkrævet, idet begrebers betydning i høj grad afspejler brugssammenhængen og den kontekst som det fungerer i i den praktiske livsverden.

Det er herefter muligt at tildele relevante emneord, som er væsentlige for brugergruppen samt samle begreberne i beslægtede grupper, der er præget af brugernes forståelse og sociale kontekst.
Vurderes de tre feedback-faciliteter dernæst på baggrund af henholdsvis hermeneutikken og Wittgensteins teorier er navigerings-teknikken den bedst egnede set $i$ forhold til betydningsdannelsens kompleksitet, idet den afspejler den associative tankegang, som mennesket er i besiddelse af, og støtter dermed fleksibiliteten i søgeprocessen. Navigerings-facilitetens styrke afhænger dog af det faktum at den begrebsmæssige arkitektur og indekseringspaksis afspejler den pågældende målgruppe. Klyngefaciliteten er også anvendelig, dog er det særdeles påkrævet at klyngeanalyserne har en efterfølgende kvalitativ justering, idet fejlplaceringer ofte vil forekomme ved hyppighedsbaserede teknikker, og derved forvirre brugeren fremfor at støtte.

Rank/zoom faciliteten er den teknik der hviler på det mest spinkle grundlag, idet det ikke er muligt at udføre semantiske justeringer, idet faciliteten udføres under søgeprocessen og derfor præsenteres ubearbejdet for slutbrugeren.

Erkendelse af sprogets kompleksitet er særdeles vigtigt kan det således afslutningsvis konstateres, hvorfor det er helt centralt at forstå og analysere sprog og begreber i en kontekst, idet det netop er brugsforholdet $i$ en given praksissammenhæng der skaber betydning.

\section{Litteraturliste}

Bates, Marcia J. (1989)

The design of browsing and berrrypicking techniques for the online search interface. I: Online Review

Bates, Marcia J. (1986)

Subject access in Online Catalogs: A Design Model. I: Journal af The American Society for Information Science 37 (6)

Blair, D.C (1990)

Language and representation in information retrival. Oxford: Elsevier 
Brier, Søren (1994)

Information er sølv...: Om muligheden for en pragmatisk informationsteori baseret på anden ordens kybernetik, semiotik og sprogspilsteori. Aalborg: Forlaget Biblioteksarbejde

Christensen, Marianne L (1994)

Hermeneutik - fortolkning og forståelse. I: Biblioteksarbejde (41)

Ingwersen, Peter (1992)

Information Retrieval Interaction. London: Taylor Grahav

Lindholm kjær, Suzette; Møller, Hanne; Sognstrup, Helene (1994)

Ordassociationstest i teori og praksis: - en metode til forbedring af IR. Danmarks Biblioteksskole
Luria, A. R. (1976)

Cognitive Development: Its Cultural and Social Foundations. London: Harvard University

Lykke Nielsen, Marianne og Skrubbeltrang, Conni (1992)

Indekseringsstrategi og søgethesaurus for UMIinformationssystemet. Aalborg: Danmarks Biblioteksskole, s. $62-86$

Taylor, Robert S. (1968)

Question-negotiation and information seeking in libraries. I: College and Research Libraries 29 